\title{
Study on the Major Cattle Health and Production Constraints in and Around Haramaya Town, Ethiopia
}

\author{
Dr. Sultan Abda Neja* \\ Hawassa University, Faculty of Veterinary Medicine, P.O.Box 05, Hawassa, Ethiopia \\ Yonas Gari \\ Wolaita Sodo University, School of Veterinary Medicine, Wolaita, Ethiopia
}

\begin{abstract}
A Cross-sectional study was conducted from November 2018 to April 2019 to assess the major Cattle health and production constraints in and around the Haramaya town of Haramaya district, Ethiopia. First, the survey was conducted on animal owners randomly selected from four sites in the study area and followed by clinical case observation of sick Cattles that come from the area to the Haramaya Veterinary Clinic. In our study, we found Cattle (mainly local breeds) were reared in an extensive production system characterized by mixed herd composition kept under low production input in the peri-urban area for different purposes and dairy cows mainly in the town. The main production constraints are lack of feed, water and animal health problems. According to the survey as well as clinical observation, Blackleg, Mastitis, Lumpy Skin Disease (LSD), Foot and Mouth Disease (FMD), and Ringworm, Pneumonia and Fasciolosis were the top listed leading causes of mortality. We also noted parasitic and reproductive health problems that affect the quantity and quality of livestock products. This is associated with poor animal health care and extension service, lack of awareness by the farmers on how to contain the above prevailing constraints. Hence, it is recommended that basic training on Cattle health and production improvement needs to be delivered. On top of this, detail Epidemiological studies need to be conducted to evaluate disease risk factors and design the best policies for animal health and production development in the area.
\end{abstract}

Keywords: Cattle, Disease, Production, Constraints, Haramaya, Ethiopia.

DOI: $10.7176 / \mathrm{JBAH} / 10-9-01$

Publication date:May $31^{\text {st }} 2020$

\section{Introduction}

Livestock in the Greater Horn of Africa is a vital resource in promoting development. They provide $20-30 \%$ of the Gross Domestic Product (GDP), and at the farmer level, as much as $70 \%$ of cash income is generated from livestock (Ndikima et al., 2000). Livestock is used by humans to provide a wide range of products and services. Foods derived from animals are an important source of nutrients (Givens, 2010) that provide a critical supplement and diversity to staple plant-based diets (Murphey et al., 2003).

Animals and animal resources also occupy a very special place in poverty reduction programs in many African countries. Besides its significant contribution to agricultural GDP (on average 30\% of agricultural GDP in Sub-Saharan Africa and its invaluable contribution to the food security of the poor), livestock play a crucial role in social relations within communities and in inter-state trade. Meat, milk and eggs constitute around $65 \%, 27 \%$ and $8 \%$, respectively, of the value of edible livestock products (SOFA, 2009).

Ethiopia constitutes an agrarian society; the socio-economic activities of about $85 \%$ of the population are based on farming and animal husbandry (Solomon, 1994). Livestock plays a critical role in the majority of the Ethiopian population. Domestic animals are mainly used as drought animals, sources of milk, meat, hide and skin and as pack animals. Apart from this they also serve as a means of risk diversion and accumulation of wealth among the rural community (Yohannes, 2002).

Ethiopia's estimated livestock population is often said to be the largest in Africa. In the country, there were approximately 50.8 million Cattle, 25.5 million sheep, 22.78 million goats, 2.0 million horses, 0.38 million Mule, 6.2 million donkeys, 1.1 million camels and 49.3 million poultry excluding the Afar and Somali Regions (CSA, 2010).

Infectious animal diseases that are endemic, or common in a region, generate a variety of significant adverse economic consequences. Most directly, mortality, morbidity, barrenness, and miscarriage in production animals reduce technical efficiency. Costly treatments and altered management practices to ameliorate these losses also reduce profitability (Bennett et al.,2005). Diseases have numerous negative impacts on productivity and fertility of herds (losses due to mortality and morbidity, loss of weight, depressed growth, poor fertility performance, and decrease physical power (CACC , 2003). In tropical areas livestock health problems are high due to environmental factors like high temperature and humidity, topography structure of sloppy area exposed to flood so easy to infect soil-borne diseases, stress factors and drought are common in these areas as a result feed availability is limited and low vegetation coverage. And the other major reason is the lack of weakness of animal health services (Assegid, 2000). 
The disease problem is still aggravated by the changing ecological conditions which provide fertile ground for disease, affecting especially pastoral systems where there is a close physical association between people, livestock and wild animals. Viral and other pathogens benefit hugely from the dynamic state created by animal migration, and the increasing pressure on scarce resources from all human and animal populations with more frequent contact improving the opportunity for disease transmission (McPherson, 1995).

Experiences have shown that (Coopock, 1994) information on animal health had been the focus of research. However, knowing the type and extent of the common and/or major health problems is very important to livestock owners, Veterinarians, and researchers and can assist in the development of herd health strategies and the selections of possible interventions (Radostitis et al., 1994). It is highly recommended that organized research that can elucidate major animal health problems is a central issue for further study of an epidemiological study on diseases of livestock (Damte, 2003).

In the present study area, there is no recent investigation of the major Cattle health constraints and the status of livestock husbandry practices are yet to be identified and developed respectively. Therefore the objectives of this study were to characterize the Cattle production system and enquire baseline information on major health problems of Cattle in the study.

\section{Materials and Methods 2.1 Study area}

The study was conducted in and around Haramaya town of Haramaya District, the eastern part of Ethiopia at 497 $\mathrm{Km}$ from Addis Ababa. The animal production system of the district was a mixed type. Topographically, the Haramaya district is found in the eastern part of Harerghe, at an altitude of 1600-2100 meters above sea level. The amount of rainfall in the area varies among the season, with the highest rainfall of $866 \mathrm{~mm}$ being recorded from June to September and the smallest, $118 \mathrm{~mm}$, recorded in February. The mean annual rainfall recorded is $498 \mathrm{~mm}$ and the mean annual temperature is $24^{\circ} \mathrm{C}$. Geographically; it was located $041^{\circ} 59^{\prime} 58^{\prime \prime} \mathrm{N}$ latitude and $09^{\circ} 24^{\prime} 110^{\prime \prime} \mathrm{S}$ longitude. The temperature ranges from $9.5-24{ }^{0} \mathrm{C}$ with low-temperature fluctuation. The district has 34 rural kebeles and the major crops grown in the area include sorghum, maize, and haricot bean, wheat, barley, groundnut, potato, onion, chat and other vegetable crops. The most common cash crops for the district are vegetables and chat. Livestock are an important component of the farming system for consumption and source of income. The livestock rearing is mostly not greater than four herds per household because of the shortage of grazing land, the Animal feeding method is most commonly have experience cut and carry system. The district has two agro-climatic zones, where $66.66 \%$ was Weina Dega and 33.33\% was Kola. Haramaya town (Midland) is the capital town of the Haramaya district. The dominant species of animals in this area were sheep, goat, Cattle and donkey (HWRAB, 2008).

\subsection{Study population}

The target population for the questionnaire survey comprises Cattle owners of the selected sites of Haramaya district (Haramaya town and three rural kebele around Haramaya namely Tujigebisa, Bate and Demote). For clinical observation of the sick Cattle in the district, animals attended to the Haramaya veterinary clinic were randomly selected for examination.

\subsection{Study design}

A cross-sectional study was carried out from November 2018 to April 2019 in the selected sites of the Haramaya district. The questionnaire survey was conducted on a total of 100 Cattle owners in four selected sites (Haramaya town, Tujigebisa, Bate, and Demote). The sample size was determined for the questionnaire survey using the formula given by Arsham (2005). For clinical observation, the sample size was estimated using the prevalence of the common endemic disease in the area and using Thrusfield (2005), for simple random sampling with $95 \%$ confidence interval and 5\% desired precision. Accordingly, 60 sick Cattle that presented to the Haramaya veterinary clinic were randomly selected. The history of the case (origin, breed, age and sex) was recorded. Then the animals were examined and the tentative diagnosis was made. The cases were classified based on their prognosis and the data for each case were recorded for analysis.

\subsection{Data collection and Analysis}

A detail questionnaire survey was designed to generate information relates to Cattle production (demographic features of respondents, Cattle herd size, Cattle function, feeding types and availability) with particular emphasis on major health problems of Cattle in the area and measures taken by the farmers against Cattle diseases and their constraints. A total of 100 households were included in this interview. The questionnaire was administered using face to face interviews of Cattle owners randomly selected from different kebeles of the Haramaya district. On top of the survey data from the 60 clinical observations were also recorded. The collected data were stored in the Excel Microsoft (MS excel) and descriptive statistics and chi-square $(\chi 2)$ correlation analysis were performed using 
Statistical Program of Social Sciences (SPSS) version 16.0 software packages (SPSS Inc, Chicago, IL, USA). For all analysis performed, 95\% CI and P-value $<0.05$ was set for statistical significance of an estimate.

\section{Result}

\subsection{Demographic characterization of the respondents}

Demographic features of 100 respondent aca livestock owners showed that most of the interviews $(79 \%)$ were male and the rest $(21 \%)$ were female. The higher proportion of the respondents $(63 \%)$ were adults with the age range between 41-70 years and the proportion does not vary much within the different kebeles of the district. The educational background of livestock owners indicated that $41 \%$ were not having formal education (Table 1).

Table 1: Profile of the respondents' proportion by sex, age and education status

\begin{tabular}{lccccc}
\hline Description & $\begin{array}{c}\text { Tujigebisa } \\
\text { N=30 }\end{array}$ & $\begin{array}{c}\text { Bate } \\
\mathbf{N = 2 5}\end{array}$ & $\begin{array}{c}\text { Demote } \\
\mathbf{N = 2 0}\end{array}$ & $\begin{array}{c}\text { Haramaya town } \\
\mathbf{N = 2 5}\end{array}$ & $\begin{array}{c}\text { Total (\%) } \\
\mathbf{N = 1 0 0}\end{array}$ \\
\hline $\begin{array}{l}\text { Sex of respondent } \\
\text { Female }\end{array}$ & 8 & 5 & 3 & 5 & 21 \\
Male & 22 & 20 & 17 & 20 & 79 \\
Age of respondent & 10 & 6 & 7 & & 31 \\
15-40 years old & 20 & 17 & 12 & 14 & 63 \\
$41-70$ years old & 0 & 2 & 1 & 3 & 6 \\
$>70$ years old & 15 & 13 & 9 & 4 & 41 \\
Educational level & 9 & 6 & 6 & 5 & 26 \\
No formal education & 6 & 5 & 4 & 10 & 8 \\
Primary school & 0 & 1 & 1 & 6 & \\
Secondary school & & & & & \\
College/university & & & & & \\
\hline
\end{tabular}

\subsection{Cattle herd composition and production characteristics}

The average herd size and composition of cows, bulls, heifers, calves and steers per households are presented in Table 2. Cows comprise the largest proportion of the Cattle herd (29.7\%) followed by steers (24.9\%) and bulls $(17.8 \%)$. Compared to the other rural village, Haramaya City has higher Cows in percent within the heard (48\%) often kept for dairy purposes.

Table 2: Herd structure of the Cattle owned by respondents in the study area (№ and percent)

\begin{tabular}{llllll}
\hline Cattle herd types & Tujigebisa & Bate & Demote & Haramaya town & Total \\
\hline Cows & $7(23.3 \%)$ & $6(24.0 \%)$ & $5(25.0 \%)$ & $12(48.0 \%)$ & $30(29.7 \%)$ \\
Bulls & $4(13.3 \%)$ & $5(20.0 \%)$ & $5(25.0 \%)$ & $4(16.0 \%)$ & $18(17.8 \%)$ \\
Heifers & $3(10.0 \%)$ & $5(20.0 \%)$ & $5(25.0 \%)$ & $4(16.0 \%)$ & $17(16.8 \%)$ \\
Calves & $1(4.0 \%)$ & $5(20.0 \%)$ & $2(10.0 \%)$ & $3(12.0 \%)$ & $10(9.9 \%)$ \\
Steers & $16(53.3 \%)$ & $4(16.0 \%)$ & $3(15.0 \%)$ & $2(8.0 \%)$ & $25(24.9 \%)$ \\
\hline
\end{tabular}

According to the survey, animal owners keep their Cattle mainly in an extensive production system (Figure 1A). The purpose of keeping their Cattle varies but it is mostly for milk production (Figure 1B). More than $80 \%$ of the Cattle kept are local breeds (Figure 1C). The most common types of feed given to the animal are Strow, Grass, Furushka and mixed types (Figure 1D). Among the production constraints on the Cattle rearing mentioned by the animal owners, shortage of feed and disease predominates (Figure 2). 
A

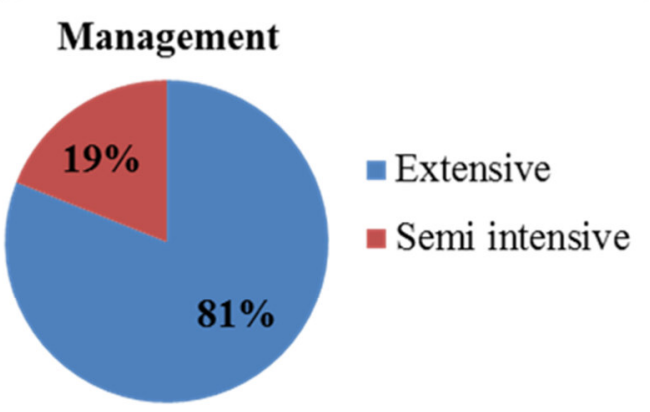

C

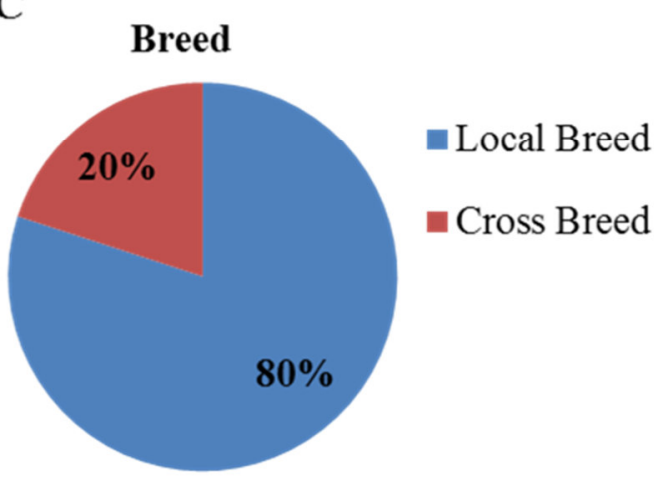

B

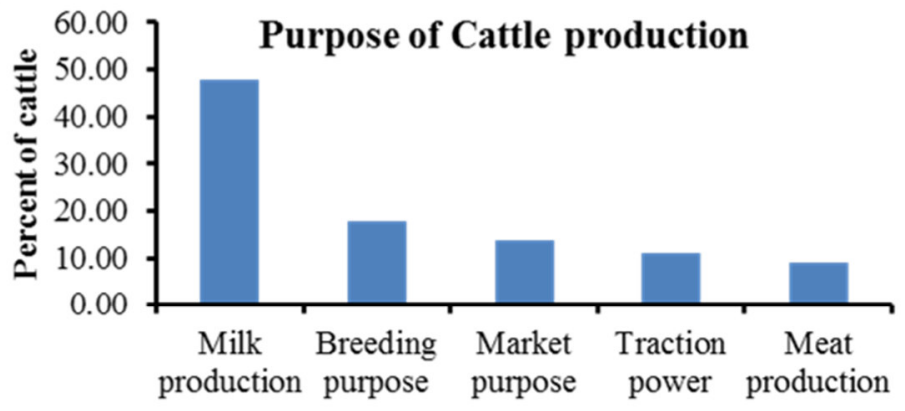

D

\section{Feed type}

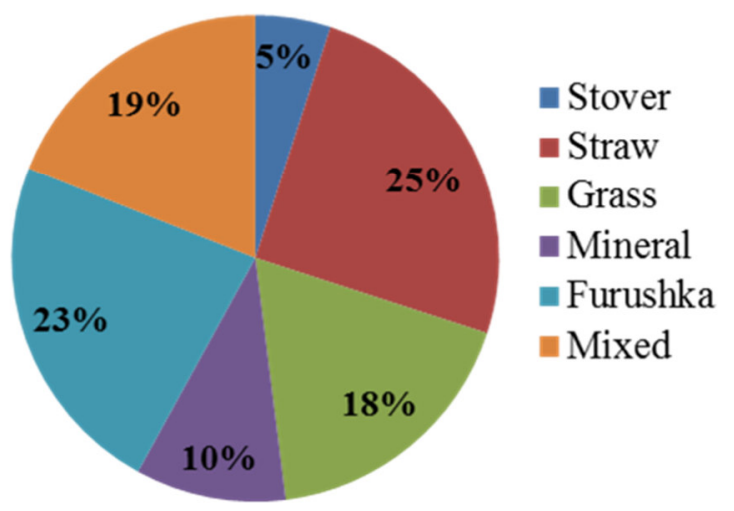

Figure 1: Cattle production and management characteristics

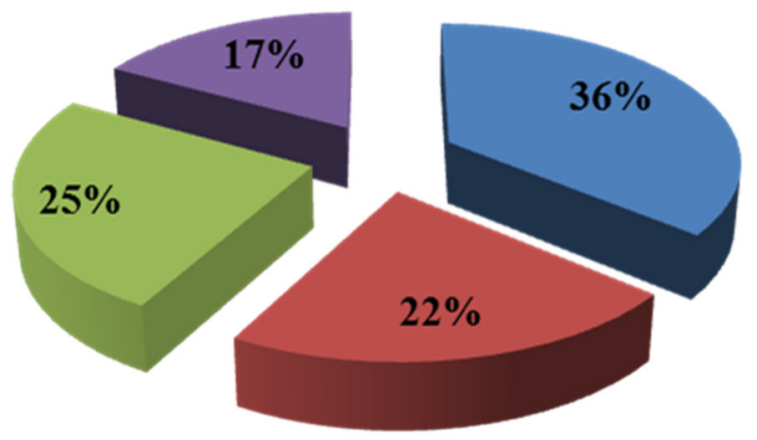

\section{Constrients}

- Shortage of feed

- Shortage of water

Disease

- Shortge of Vet Service

Figure 2: Major constraints of Cattle production in the study area

3.3 Cattle health problems identified by respondents in the study area

According to the 100 responses of the farmers on the animal disease they experienced, Blackleg, mastitis, FMD and LSD are the most common disease (Table 3 Based on the farmer's response, there is no significant difference in the disease distribution between the four sites. 
Table 3: Common suspected disease reported by farmers ( $\mathrm{N}$ in number and \% in percent)

\begin{tabular}{|c|c|c|c|c|c|c|c|c|c|c|c|}
\hline \multirow[t]{2}{*}{ Scientific Name } & \multirow{2}{*}{$\begin{array}{l}\text { Local } \\
\text { Name }\end{array}$} & \multicolumn{2}{|c|}{ Tujigebisa } & \multicolumn{2}{|c|}{ Bate } & \multicolumn{2}{|c|}{ Damot } & \multicolumn{2}{|c|}{ Haramaya town } & \multicolumn{2}{|c|}{ Total } \\
\hline & & $\mathbf{N}$ & $\%$ & $\mathbf{N}$ & $\%$ & $\mathbf{N}$ & $\%$ & $\mathbf{N}$ & $\%$ & $\mathbf{N}$ & $\%$ \\
\hline Blackleg & Abagurba & 3 & $10.00 \%$ & 4 & $16.00 \%$ & 1 & $5.00 \%$ & 4 & $16.00 \%$ & 12 & $12.00 \%$ \\
\hline Mastitis & Jigo & 2 & $6.70 \%$ & 3 & $12.00 \%$ & 3 & $15.00 \%$ & 4 & $16.00 \%$ & 12 & $12.00 \%$ \\
\hline FMD & Maansa & 3 & $10.00 \%$ & 3 & $12.00 \%$ & 3 & $15.00 \%$ & 2 & $8.00 \%$ & 11 & $11.00 \%$ \\
\hline LSD & Massa & 3 & $10.00 \%$ & 3 & $12.00 \%$ & 2 & $10.00 \%$ & 3 & $12.00 \%$ & 11 & $11.00 \%$ \\
\hline Pneumonia & Qufaa & 2 & $6.70 \%$ & 2 & $8.00 \%$ & 1 & $5.00 \%$ & 3 & $12.00 \%$ & 8 & $8.00 \%$ \\
\hline Ringworm & Robbii & 3 & $10.00 \%$ & 1 & $4.00 \%$ & 1 & $5.00 \%$ & 2 & $8.00 \%$ & 7 & $7.00 \%$ \\
\hline Fasciola & Cori & 2 & $6.70 \%$ & 1 & $4.00 \%$ & 2 & $10.00 \%$ & 1 & $4.00 \%$ & 6 & $6.00 \%$ \\
\hline Abortion & Gatata & 1 & $3.30 \%$ & 1 & $4.00 \%$ & 1 & $5.00 \%$ & 2 & $8.00 \%$ & 5 & $5.00 \%$ \\
\hline Pasteurella & Gororsa & 1 & $3.30 \%$ & 1 & $4.00 \%$ & 1 & $5.00 \%$ & 1 & $4.00 \%$ & 4 & $4.00 \%$ \\
\hline Wound & Madaa & 1 & $3.30 \%$ & 1 & $4.00 \%$ & 1 & $5.00 \%$ & 1 & $4.00 \%$ & 4 & $4.00 \%$ \\
\hline Mite & $\begin{array}{l}\text { Chittoo } \\
\text { Dildhuun }\end{array}$ & 1 & $3.30 \%$ & 1 & $4.00 \%$ & 1 & $5.00 \%$ & 1 & $4.00 \%$ & 4 & $4.00 \%$ \\
\hline Retained placenta & hafuu & 2 & $6.70 \%$ & 1 & $4.00 \%$ & 1 & $5.00 \%$ & 0 & $0.00 \%$ & 4 & $4.00 \%$ \\
\hline Lice & Injirre & 1 & $3.30 \%$ & 1 & $4.00 \%$ & 1 & $5.00 \%$ & 0 & $0.00 \%$ & 3 & $3.00 \%$ \\
\hline Tick & Silmii & 1 & $3.30 \%$ & 1 & $4.00 \%$ & 0 & $0.00 \%$ & 1 & $4.00 \%$ & 3 & $3.00 \%$ \\
\hline Actinomycosis & Dhulla & 2 & $6.70 \%$ & 1 & $4.00 \%$ & 0 & $0.00 \%$ & 0 & $0.00 \%$ & 3 & $3.00 \%$ \\
\hline Bloat & Bokoka & 1 & $3.30 \%$ & 0 & $0.00 \%$ & 1 & $5.00 \%$ & 0 & $0.00 \%$ & 2 & $2.00 \%$ \\
\hline Leech & Ulaandhula & 1 & $3.30 \%$ & 0 & $0.00 \%$ & 0 & $0.00 \%$ & 0 & $0.00 \%$ & 1 & $1.00 \%$ \\
\hline
\end{tabular}

Table 4: Mortality of Cattle in the past year (2009/2010)

\begin{tabular}{|c|c|c|c|c|c|c|}
\hline Types of Cattle dead & $\begin{array}{c}\text { Tujigebisa } \\
\mathbf{N}\end{array}$ & $\begin{array}{c}\text { Bate } \\
\mathbf{N}\end{array}$ & $\begin{array}{c}\text { Demote } \\
\mathbf{N}\end{array}$ & $\begin{array}{c}\text { Haramaya town } \\
\mathbf{N} \\
\end{array}$ & $\begin{array}{c}\text { Overall } \\
\mathbf{N}\end{array}$ & $\begin{array}{c}\text { Percent } \\
\% \\
\end{array}$ \\
\hline Cows & 34 & 25 & 35 & 21 & 115 & 28.68 \\
\hline Bulls & 20 & 18 & 30 & 16 & 84 & 20.95 \\
\hline Heifers & 17 & 13 & 15 & 14 & 59 & 14.71 \\
\hline Calves & 30 & 41 & 25 & 47 & 143 & 35.66 \\
\hline Total & 101 & 97 & 105 & 98 & 401 & 100 \\
\hline
\end{tabular}

On top of identifying the prevailing disease type, we also accessed the estimated disease burden in the area. According to the 100 respondents, a total of 401 animals died during the past year (2009/2010) in Haramaya town and the three rural kebeles (Table 4). From the total estimated number of animals died from the herd in the area, the higher proportion were calves (35.66\%) followed by dairy cows $(28.68 \%)$ of the (Table 4). Based on the response of the Cattle owner that lost their animal (Table 3)the most significant constraints affecting animal was a shortage of feed $(p=0.029)$ and disease occurrence $(p=0.011)$. To consolidate our retrospective and farmer's responses in the survey, we decided to investigate the disease pattern in the area at the clinic level.

\subsection{Clinical case observation of Cattle presented to Haramaya Veterinary Clinic}

To investigate the present clinical cases in the study area, Haramaya veterinary clinic was used and 60 Cattle come to the clinic were randomly selected. Upon taking the case history, clinical diagnosis was conducted in each selected animals. The origin of animals includes the kebeles where the survey was conducted (Tujigebisa, Bate Damot and Haramaya) plus other additional four kebeles around the study area. The number of Cattle sick animals per kebele presented to the clinic is indicated on the bar graph (Figure 3A). The breed of the animals was mainly local breeds (Figure 3B) and 92\% of the diseased animals expected to have a good prognosis (Figure 3C). Among the top diseases, which were diagnosed tentatively at the veterinary clinic were Blackleg, Mastitis, FMD and LSD (Figure 3D). More interestingly the correlation analysis shows there is a significant correlation between the pattern of disease ranked during the survey as well as during clinical observation $(p=0.001)$. 
A

D
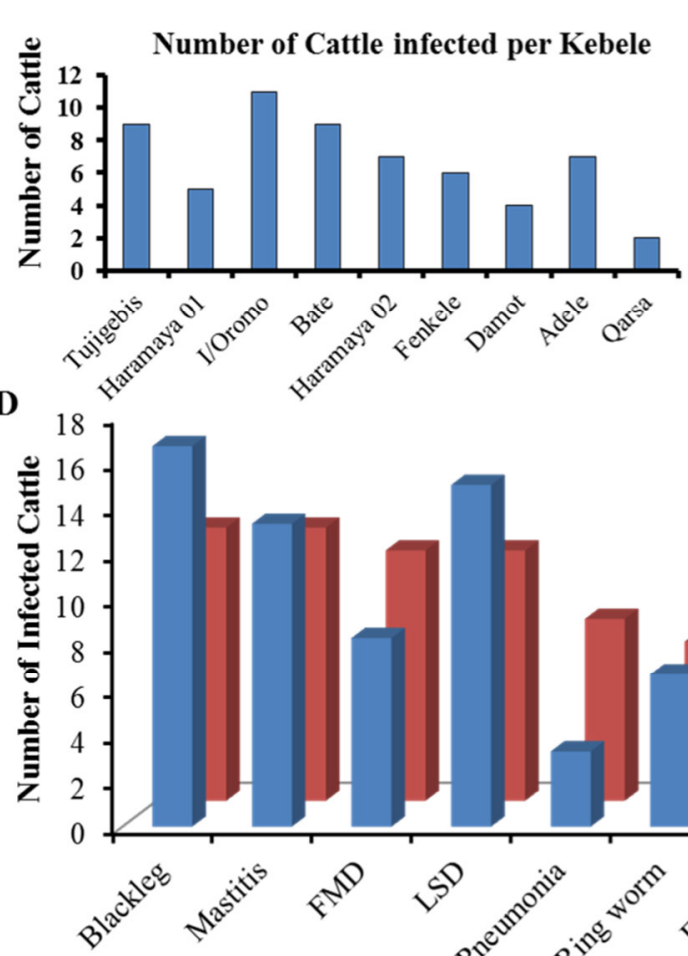

B

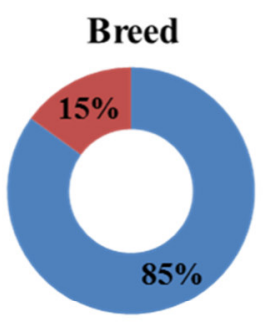

C

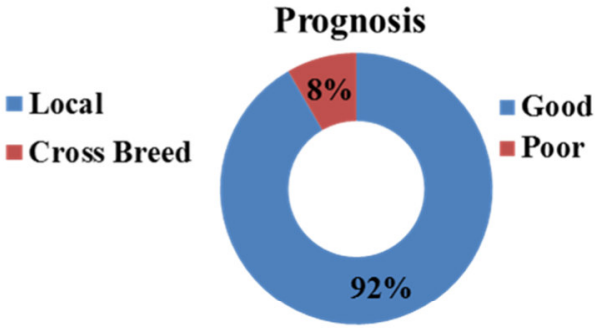

n Clinical cases

Survey response
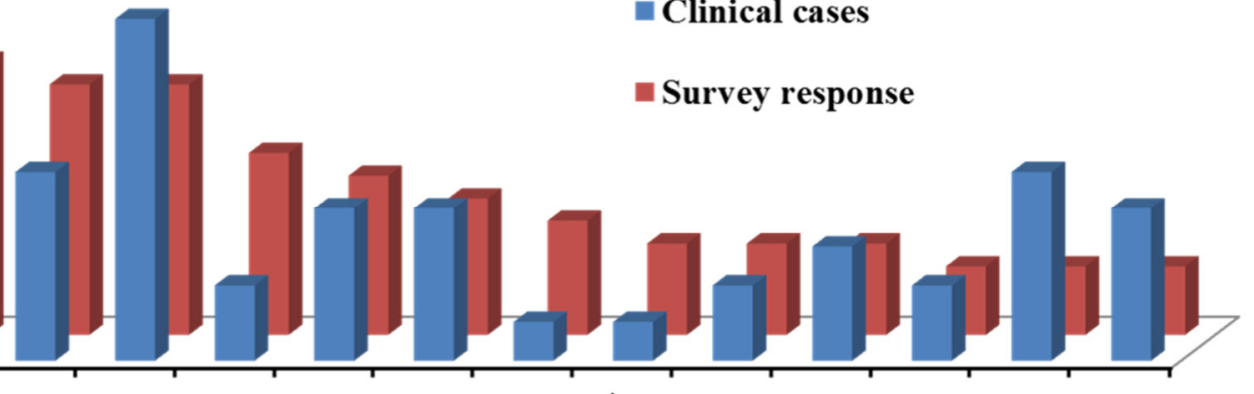

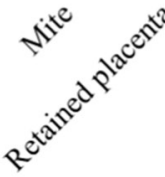

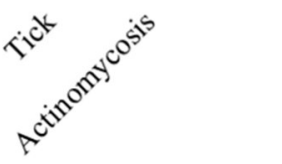

Figure 3: Clinical cases Observation A) Number of Cattle infected per kebele they originate. B) Cattle breed type present to the clinic. C) Prognosis of the clinical cases. D) Number of Cattle infected per the prevailing disease. The correlation analysis was made using the number of animals infected by the disease described by the survey respondent versus the number of clinical cases observed (tentatively diagnosed) at the veterinary clinic. The bar graph was used to plot the data and Correlation was considered significant at the 0.01 level (2-tailed).

\section{Discussion}

This survey showed that the predominant production system is an extensive production of a mixed-livestock population of mainly local breeds. Animal management is found a duty of adult men who do not have formal education or training. Cattle are the dominant livestock species present in the area. The diverse Cattle herd composition also reflects that the animals were kept for different purposes. The farmers kept Cattle mostly for milk, breeding and market/sell and traction power reflecting the herd structure of Ethiopia (Kuastros, 2007). In Haramaya city however local and cross-bred Dairy cow is mainly raised. This could be due to the availability of the milk market compared to rural villages (Belay 2013, Azage et al., 2000).

In this area, since food crop cultivation as the first priority; land allocated for grazing is very limited. Thus according to the respondent animal feed are mainly agricultural products (Straw and Frushka) and cut and carry grasses. Since the availability of these animal food and surface water is seasonal farmers listed animal feed and water as the main constraints for the Cattle development in the area. A similar finding has been reported (Belay, 2013). Although mixed animal feed and pipe-line water are available in the city, it is expensive and often hard to obtain throughout the year.

Based on the result of this study livestock diseases and their consequences have a severe impact on the smallholder farmers' livelihood directly and indirectly. The major restraints to alleviate animal health problems include low quality and inadequate animal health services, minimum attention to the services, low and/or no private sector involvement (Belay, 2013). According to the respondent's history of Cattle mortality within the herd, Calves showed higher mortality followed by Cows. This could be due to the presence of unvaccinated Calves for the common endemic disease prevailing in the area. The vaccine is often given once a year (FAO, 2019).

On top of the animals' health, animal diseases have also been indicated as public health hazards (Assegid, 2000). For instance, Zoonotic disease like a Black leg (16.8\%) was one of the most mentioned infections of Cattle as described by respondents in the study area. All of the respondents describe blackleg to affect all age and sex groups of Cattle except calves. Although the degree varies as found in heifer, cows and bulls as found in this study. This is consistent with that described by (Radostits et al., 1994) regarding the incidence of the diseases that is high when calves reach the susceptible age group which is largely confined to young stock between the age of 6 months 
and 2 years. The blackleg was also reported to be the most important infectious disease with a prevalence rate of $20 \%$ in the north part of Ethiopia (Leggess, 1996). Furthermore, the diseases were claimed to be the leading Cattle health problem together with anthrax in Ginchi water shade areas as reported by (Esthete et al., 2002).

Mastitis was also the second most important disease affecting cows as mentioned by $11.9 \%$ of the interviewed farmers. Dairy Cows are at risk of acquiring mastitis when there are improper milking and poor udder health management like preventing teat from lesion causing agents like tick infestation (Quinn et al., 1994). Mastitis was one of the most economically important multi-causal infections of cows in the study area.

A lumpy skin disease $(10.9 \%)$ is the other important infectious viral disease that is revealed in this questionnaire survey. This agrees with the findings of (Tesfahiwet, 2004) in that LSD was an important infectious disease in Adaaliben district, central Ethiopia. Other reports also showed that lumpy skin disease was also common in Alamata district and Alaba district in northern Ethiopia, (Yohannes, 2007). LSD has very high morbidity and moderate mortality. Its transmission from infected to the healthy animal is high, as a result, it mostly occurs as an outbreak and this could be the reason that makes it a very common disease mentioned by farmers, furthermore it may be also due to low prevention measures like vaccination. LSD was important because of the presence of the insect vector in the endemic area.

Foot and mouth disease (FMD) was the most important disease affecting Cattle as mentioned by $9.9 \%$ of the Respondents. FMD was the most important disease affecting Cattle (Molla et al., 2012, Haftu et al., 2014). The higher occurrence of the disease was because there are high animal movements and higher contact patterns of domestic animals to wild animals.

Pneumonia $(5.8 \%)$ was the main respiratory problem of Cattle in the study area. The occurrence of this problem might be due to stress; workload and movement of animals during the drought period that can favor the bacteria to multiply due to the immune status of the animals were suppressed. Environmental risk factors include close confinement and poor ventilation of the house, the high temperature that encourage replication of the diseases. According to indicated that the disease is common when animals are exposed to wet, chilly weather or exhausted by heavy work (Radostits et al., 1994).

Among the parasitic infection, Fasciolosis $(4.9 \%)$ was one of the common endoparasites that affect the productivities and growth rate of Cattle in the study area. The most probable reason may be due to the tendency of farmers to feed their animals in marshy areas due to the shortage of grazing land (Ameni et al., 2001). The other cause of Cattle parasitic health problems was ectoparasitism such as tick infestation, mange mites, and lice are known to cause general skin problems (Bedasso et al., 2014, Chalachew, 2001). The respondents considered this as an important health problem in Cattle and high occurrence in the rainy season and due to grazing in the area near Lake Haramaya (Belay, 2013). Thus according to the views of the respondents, skin problems cause a reduction of skin and hide quality, the productivity of live animals and occasional death will result. Skin diseases are the major problem in Cattle and widespread in the district. This is due to lack of sufficient veterinary service, lack of control and prevention using different acaricide which affects the incomes of farmers, the economy of the area and market opportunities of the livestock.

Cattles were also reported to be affected by Abortion, bloating, wounds and retained placenta. This could be attributed to various predisposing factors to which the animals are subjected. Among which nutritional status and poor dairy Cow production management around the peri-urban area of Haramaya city can be mentioned. The present finding is in agreement with the reports of Yohannes (2007) and Mamo (2004). Such management constraints would have been reduced by intensive animal healthcare service and awareness creation to the farmers.

From the on-spot clinical observation of the animal disease cases, a similar pattern of disease distribution was observed across the breed and herd composition of sick animals presented from the area into the Haramaya veterinary clinic. This finding gives strength to the above survey report for which Blackleg, Mastitis, FMD and LSD was top listed.

\section{Conclusion}

The present study revealed that Cattle health problem is the forefront problem of Cattle production and development programs in and around Haramaya town. In this area livestock (mainly local breed Cattles) are kept in an extensive production system. The production is characterized by mixed herd stock kept for different purposes under low production input. Dairy Cows mainly kept in the town for milk production. The most predominant production challenges are lack of feed, water and animal health problems. According to the survey and clinical observation, Blackleg, Mastitis, LSD, FMD, and Ringworm, Pneumonia and Fasciolosis were the top listed leading causes of mortality. On top of this skin disease, abortion and other reproductive problems are also found to cause production losses, reduce growth rate, reduce the reproduction ability of animals, downgrade of livestock products (hides and skins) and incurs public health hazards. Such production constraints in the study areas perceived by the households were due to poor animal health care and extension service, lack of awareness by the farmers on how to contain the above-prevailing animal health and production constraints. Hence based on the above conclusion the following recommendations were forwarded. Further epidemiological studies on the disease risk factors need 
to be conducted. Equipping the established veterinary clinic with necessary facilities, drugs and animal health professionals could be important to prevent and control Cattle disease in the study areas. Livestock owners must receive basic training regarding animal disease prevention, modern techniques in animal husbandry and management.

\section{Acknowledgments}

The authors acknowledge Hawassa University and Wolaita Sodo University for internet facility and materials used to write-up this manuscript. We thank Haramaya district animal resource, development and veterinary agency team members and other study participants for their time and assistance.

\section{Competing interests}

The authors have no conflict of interest to declare.

\section{Authors' Contributions}

Sultan Abda Neja designed the project and analyzed and drafted the manuscript. Yonas Gari participated in data collection and critical evaluation of the manuscript. Finally, both authors read and approved the final manuscript.

\section{Data Availability Statement}

The corresponding author can be reached for any data enquiry.

\section{Funding Statement}

Nil

\section{References}

Ameni G, Erko B, Bogale T., (2001). Preliminary study on bovine trematode infections around Kemissie, North Eastern Ethiopia and treatment trials with Praziquantel. Bull. Anim. health Prod. Afr. 2: 62-67.

Arsham H., (2005). Questionnaire design and survey sampling. 9th edition, http://home.ubalt.edu/ntsbarsh/statdata/surveys.htm (Retrieved August 2010).

Assegid W., (2000). Constraints to livestock and its products in Ethiopia: Policy implications. DVM Thesis, FVM, Addis Ababa University, Debrezeit, Ethiopia.Pp.97

Azage T., Million, T., Alemu, Y. and Yoseph, M., (2000). Market-oriented urban and peri-urban dairy systems. Urban Agricultural Magazine (The Netherlands). PP. 23-24

Bedasso M., Abebe, B., \& Degefu, H. (2014). Species composition, prevalence and seasonal variations of ixodid Cattle ticks in and around Haramaya town, Ethiopia. Journal of Veterinary Medicine and Animal Health, 6(5), $131-137$

Belay D., (2013). Smallholder livestock production and marketing systems in the Haramaya district, eastern Ethiopia. Basic Research Journal. 2(6) Pp. 122-129.

Bennett R, Ijpelaar J., (2005). Updated Estimate of the cost Associated with thirty-four Endemic Livestock Diseases in Great Britain: A note. J Agric Econ 56: 135-144.

CACC Central Agriculture Census Commission, (2003). Ethiopian Agricultural Sample Enumeration, Land Use 2001-2002 (1994 E.C), Addis Ababa, Ethiopia. pp: 29-43.

Chalachew N., (2001). Study on Skin Disease in Cattle, Sheep, and Goats in Around Welayta Soddo South. Addis Ababa University, Faculty of Veterinary Medicine, Debrezeit, Ethiopia. DVM. Thesis. Pp 1-45.

Coopock (1994). The Borena plaute of southern Ethiopia. Synthesis of pastoral research, development and change, 1986-91. System study. International Livestock Center for Africa (ILCA), Addis Ababa, Ethiopia. Pp.4.

CSA (2010). Agricultural sample survey, 2009/10 (2002 E.C). Volume II, report on livestock and livestock characteristics. Statistical bulletin, 331, March 2010, Addis Ababa, Ethiopia.

Damte D., (2003). Major health problems of Cattle and camel in the field and abattoir, around Dire Dawa. DVM Thesis, Pp 24.

Esthete G, Yami A, Baars R., (2002). An assessment of feed resources, their management and impact on livestock productivity in Ginchi watershed area. MSc Thesis Presented to School of Graduate Studies of Haramaya University, Haramaya, Ethiopia.

FAO (2004) Transboundary Animal Diseases. Assessment of socio-economic impacts and institutional responses. Livestock policy discussion paper No 9. Otte MJ, Nugent R,et al. (Eds.), Food and Agriculture Organization. Livestock Information and Policy Branch, AGAL, Pp. 46.

FAO (2019). Livestock, health, livelihoods and the environment in Ethiopia. An integrated analysis. Food and Agriculture Organization of the United Nations. Rome, 2019. Pp. 41.

Givens DI, (2010). Milk and meat in our diet: good or bad for health? Animal 4: 1941-1952.

Haftu B, Asresie A, Haylom M., (2012). Assessment on Major Health Constraints of Livestock Development in Eastern Zone of Tigray: The Case of "Gantaafeshum Woreda" Northern Ethiopia. J. Veterinary Sci Technol 5: 174 .

HWRAB 2008. Haramaya wereda Rural and Agricultural Development Beriou: Basic data of Haramaya.

Kuastros M., (2007). Major animal health problems of market oriented livestock development in Alaba woreda, 
NE US Academic Publisher. DVM thesis, FVM, Addis Ababa University, Debrezeit, Ethiopia. Pp.21.

Leggess G., (1996). Livestock Health Conditions in Central Tigray. In: Rural Exploratory Studies Processing of a Workshop. OyhusAO, Gebru G (eds). Agricultural University of Norwegian (AUN). pp: 85-100.

Mamo T., (2004). Study on major postpartum reproductive problems of smallholder dairy cows in and around Debre Zeit. DVM Thesis, Faculty of Veterinary Medicine Addis Ababa University, Debre Zeit, Ethiopia.

McPherson, C.N.L., (1995). Transhumance on the epidemiology of animal diseases. Preventive Veterinary Medicine 25(2):213-224

Molla B, Ayelet G, Asfaw Y, Jibril Y, Gelaye E., (2014). Participatory epidemiology and associated risk factors of foot-and-mouth disease in Cattle in South Omo zone, South-Western Ethiopia. J. Vet., and Animal Health. 5(11), Pp. 322-328.

Murphey SP, Allen LH., (2003). Nutritional importance of animal source foods. J Nutr 133: 3893-3897.

Ndikima S, Suth J, Kamadi R, Ossera S, Marambi R., (2000). Coping mechanisms and their efficiency in disasterprone pastoral system of the greater horn of Africa. Effect of the 1995-1997 draught and the 1997-1998 ELNINO rains and response of pastorals and livestock. International Livestock Research Institute (ILRI), Nairobi, Kenya. Pp: 2-4.

Quinn PJ, Carter ME, Markey B, Carter GR., (1994). Clinical veterinary microbiology. Wolfe Publishing, London. Pp. 21,175-179.

Radostitis O.M, Blood, D.C. and Gay, C.C., (1994). Veterinary Medicine: a test book of the diseases of Cattle, sheep, pigs, goats and horses, 8ed. Baillaiaere Tindall, London. Pp 652-656.

SOFA (2009). The state of food and agriculture, livestock in the balance. Asia Pacific J. Clin. Nutri. 17(1): 103105.

Solomon B., (1994). Privatization of animal health service Sub-program proceeding of the 18th Annual Conference of Ethiopia veterinary Association, Addis Ababa Ethiopia. Pp.56-6

Tesfahiwet Z., (2004). Major Health problem of livestock in the Yirer watershed, Ada liben Woreda, Southeastern Shoa, DVM thesis, Faculty of Veterinary Medicine, Addis Ababa University, and Debre Zeit, Ethiopia.

Thrusfield M. (2005). Veterinary epidemiology 3rd ed., UK, Black well Science. pp. 178-197.

Yohannes A., (2002). Background information on Contagious Bovine pleuropneumonia in Ethiopia.

Yohannes T., (2007). Major animal health problems of market-oriented livestock development in Alamata. Woreda, DVM thesis, Faculty of Veterinary Medicine, Addis Ababa University, Debre Zeit. 